\title{
Synergism of climatic variables and forest burns in the State of Acre
}

\author{
Sonaira S. Silva ${ }^{1}$, Liana O. Anderson ${ }^{2}$, Philip M. Feanrside ${ }^{3}$, Marcus A. Liesenfeld ${ }^{l}$, Igor Oliveira ${ }^{l}$, \\ Thiago Morello ${ }^{4}$, Francisco Salatiel Clemente ${ }^{l}$, , Marllus Rafael N. Almeida ${ }^{l}$, Adriele Karlokoski ${ }^{1}$, Tiago \\ Lucena da Silva ${ }^{1}$, Luiz E. O. C. Aragão ${ }^{5}$, Foster Brown ${ }^{16}$, Jessica Costa ${ }^{1}$, Antonio Willian F. Melo ${ }^{1}$, \\ Paulo Maurício L. A. Graça ${ }^{1}$, Paulo M. Brando ${ }^{6,7}$, Ane Alencar ${ }^{7}$
}

\begin{abstract}
${ }^{1}$ Universidade Federal do Acre (Ufac), Cruzeiro do Sul, Brasil; ${ }^{2}$ Centro Nacional de Monitoramento e Alertas de Desastres Naturais (Cemaden), São José dos Campos, Brasil; ${ }^{3}$ Instituto Nacional de Pesquisas da Amazônia (Inpa), Manaus, Brasil; ${ }^{4}$ Universidade Federal do ABC, (UFABC), São Bernardo do Campo, Brasil; ${ }^{5}$ Instituto Nacional de Pesquisas Espaciais (Inpe), São José dos Campos, Brasil; ${ }^{6}$ Woods Hole Research Center (WHRC), Falmouth, Estados Unidos; ${ }^{7}$ Instituto de Pesquisa Ambiental da Amazônia (IPAM), Brasília, Brasil

${ }^{*}$ E-mail para contato: salatielclemente@gmail.com
\end{abstract}

\begin{abstract}
We aimed to understand the role of precipitation and temperature in the incidence of forest burns in the State of Acre, Brazil. In the last 40 years forest burns became more frequent, occurring each four-five years in different parts of the Amazon basin. Spatial and temporal distribution of forest burns is commonly associated with extreme dry caused by anomalous increase of temperature of ocean surface. In the Southern and Southwestern Amazon, where State of Acre is located, two recent extreme dry events (2005 and 2010) is associated with increase of temperature of tropical ocean surface in the Northern Atlantic. Herein, we selected consecutive number of days without rain $(\mathrm{P} \downarrow)$ and number of days with maximum temperature above $35^{\circ} \mathrm{C}\left(\mathrm{T} \uparrow 35^{\circ} \mathrm{C}\right.$ ) to investigate potential relation with total annual cumulative area of forest burn scars in the municipality of Rio Branco between 1984 and 2018. Climate data were gathered from rain stations within study area. Years of incidence of extreme dry in the State of Acre were registered in 2005, 2010 and 2016, totalizing 526,289 ha, which correspond to $98 \%$ of mapped burns. These years match with periods of more than 40 days consecutively without rain and more than 38 days with maximum temperature above $35^{\circ} \mathrm{C}$ daily. Moreover, strongest recorded El Niño took place in 2016, which caused 66 days with $\mathrm{T} \uparrow 35^{\circ} \mathrm{C}$. During 2017 and 2018 more than 30 days with $\mathrm{T} \uparrow 35^{\circ} \mathrm{C}$ and $\mathrm{P} \downarrow$ were registered, contributing to the incidence of forest burn of 895 and 262 ha, respectively. In the first 20 years of monitoring, when it begun, large forest burns occurred each 10 years (1987 and 1998). Then, in the last decade, the frequency of severe forest burns increased to each five years (2005, 2010 and 2016). Overall, average interval between massive forest burns occurred in 1984 and 2018 was 7.25 years. We believe that increasing frequency of extreme climate events and forest burns is likely leading to a new fire regime, a climate "new normal", virtually boosting incidence of forest burns within the region in near future.
\end{abstract}

Keywords: Amazonia, temperature, extreme dry. 